\title{
Curriculum Development in Hospitality and Tourism Higher Education: challenges and gaps
}

\author{
Indra Kusumawardhana \\ ikusumawardhana@binus.edu \\ Tourism Department, Faculty of Economic and Communication, Bina Nusantara University, Jakarta \\ 11480, Indonesia
}

\begin{abstract}
The positive growth of the travel and tourism industry in the 20th century is set to continue in the 21 st century. This phenomenon creates a number of challenges for travel and tourism educators who have to respond accordingly. However, it appears hospitality and tourism education society has evolved in a heterogeneous and ad hoc manner and does not necessarily meet the needs of the travel and tourism industry. This is because there are many challenges and gaps involved in the curriculum development process. And, we should recall that this development process is intended to enhance the graduates' knowledge and skills, and employability in the sector. The current issue is to understand all partners in the knowledge exchange and transfer process - students, teachers, institutions and the hospitality industry - with the aim to enhance teaching and learning outcomes through quality curricula. Subsequently, through systematic literature review and multi stages of analysis in the research tradition, the article shows four critical thematic obstacles for educator of tourism and hospitality higher education in dealing with curriculum development such as (1) the need of information and communication technologies (ICT), (2) human resources issues on graduate's competency, job, and career aspiration, (3) curriculum content towards knowledge and skill formulation that aligned with the industry and business expectation, (4) a high-quality education that produces effective teaching \& learning strategy and significance research impact. The dimension of social sciences study reflects this study's attention to draw constructivist educational theories to understand the possible approaches focuses upon a particular sphere, which predominantly recognize the wake of the industry's dynamic growth in the light of the curriculum study and hospitality and tourism discipline. After all the study highlights the aim of educational curriculum is to create the 'complete learner' rather than merely concentrating upon what curriculum needs to offer-as it is not possible to incorporate all existing knowledge in one particular curriculum..
\end{abstract}

Keywords: Curriculum, constructivism, higher education, hospitality and tourism.

\section{Introduction}

Since the beginning of the 1960s until today, modern tourism industry had steadily grown in producing a number of employment opportunities and proved resilience towards an economic crisis [1]. Moreover, it is one of the largest industries that important socially, culturally and environmentally [2]. Furthermore, over the past six decades, World Tourism Organization (UNWTO) reassured that the increasing number of international tourist arrivals in all continents should and would contribute to a global development [3-7]. 
On the other hand, the renovation of the international educational approach started a debate and spark a research idea towards a future direction for T\&H education $[8,9]$. In particular, the dialogue was about creating $\mathrm{T} \& \mathrm{H}$ future aimed to impact on the national socio-economic progress, in terms of jobs, growth, infrastructure development, government, flexible education, curriculum and pedagogy [10].

However, it turns to be challenging as Butler and Jones [11] stated that the "tourism workforce is typically described as having low ability and few skills". Hence, the T\&H curriculum literature was relatively limited [12]. Indeed, studies have highlighted and urged $\mathrm{T} \& \mathrm{H}$ society to recognize the need for improvement in a way that industry actors and academic colleagues to collaborate as well as having mutual understanding towards a future challenge [13-15]. Thus, T\&H scholars have stimulated an idea and proposed a new approach for a creative and innovative rethink of traditional teaching models, pedagogies, learning styles towards construction of goods and services in the structure and delivery of programmes, infrastructure and resources (see Tribe [16] for the philosophic practitioner (PP), Dredge, Benckendorff [17] on the philosophical practitioner education (PPE) and Caton [18] towards liberal education).

Nonetheless, in addition to Thomas [19] and Avornyo [20] that worried about the challenges and fostering closer collaboration between the T\&H industry and tertiary institutions were still in place. It seems T\&H educator has evolved in a heterogeneous and ad hoc manner in order to enhance the competitiveness of the programmes by meeting an uncertainty future, particularly in anticipating the curriculum challenges and gaps regards a development approach.

Therefore, it is possible to activate a comprehensive and systematic evaluation study with intention to make $\mathrm{T} \& \mathrm{H}$ educational curriculum analysis crucial since the educators need to identify and address challenges and gaps, rethink current practices to produce an educated the workforce. This new workforce must be able to meet the needs and wants of global consumers, thereby giving the employer a competitive advantage. The way forward needs to recognize a possible curriculum development approach to enhance the competitiveness of graduates economically and socially responsible.

The article starts with a reviewing the current understanding of curriculum development within T\&H discipline study. Following a brief discussion of possible reason why the comprehensive understanding of curriculum approach is important prior a development approach. The discussion then briefly illustrates and considerate the multi-stages of coding extraction derived from $\mathrm{T} \& \mathrm{H}$ curriculum publication towards thematic analysis pertaining the challenges and gaps issues. The paper concludes with the liberty to suggest a T\&H educator to acknowledge the four obstacles in dealing with curriculum development and promote constructivist educational theories to recognize the wake of the industry's dynamic growth in creating the future development of T\&H curriculum.

\section{T\&H Curriculum Development}

Curriculum is the heart of education [21]. In this sense, development of curriculum is becoming central for accomplishing an aim of education. In the higher education landscape, many scholars attempt to discuss about curriculum development such as Ackerman [22] who argued that curriculum development has reached beyond their nature to include both a strategic process challenge as well as a policy challenge such a policy to teach, value to be embedded in the subject disciplines, and preparation for competition in globalization world or even 
personalized curriculum which understand students as partners in learning process. Furthermore, Rogers and Taylor [23] described that curriculum development as all the way in which training or the teaching organization plans and guides the learning process that can take place in an institutional setting such as school, college or training centre, inside or outside a classroom, or in a village or a field, regardless the number of learner, whether in groups or individual based. Whereas, Carl [24] importantly stressed that depending on the perception of defining what curriculum is and how curriculum is developed, the determination of how the development process would be matter. In specific, Lunenburg [25] suggested to define what curriculum development in the first place with the purpose to understand the way to develop it and observed the development process through modelling.

In respect of T\&H curriculum development approach, while, Inui [26] believed to balance the vocational and liberal aspects of tourism education is vital to produce a well-rounded graduate, a graduate with philosophical and sociological foundation for decision-making strategies as well as for professional profession preparation. There are particular narratives that could considerate as modelling references regards $\mathrm{T} \& \mathrm{H}$ curriculum development approach. T\&H scholars suggested an implementation of the philosophic and vocational ends to face the educational future approach by emphasising the $\mathrm{T} \& \mathrm{H}$ transfer knowledge towards a liberal social science that aimed to develop the understanding, wisdom and criticality creates a space for a philosophical and sociological questions within the curriculum space. This suggestion brought forward by Tribe [27], Tribe [28], Tribe [29] who recommended that tourism curriculum should aim at educating "Philosophic Practitioners (PP)" which provide both liberal and vocational education, while developing students' ability to reflect and act. Thus, a decade later, Dredge, Benckendorff [17] advanced the PP proposal and suggested "Philosophic Practitioner Education (PPE)" to actualizing the possible future of T\&H curriculum.

The others believed that the big portion on the curriculum space should incorporate an applied, skills-based education that prepare a learner for a job-ready graduates. The model introduced by Morrison and O'Mahony [30] and Caton [18] who confronted the curriculum against old-fashioned hospitality paradigm and management practices towards liberation from traditional mind set to rejuvenate and discover the future alternative vision of $\mathrm{T} \& \mathrm{H}$ management. The aimed which deliver in higher education institution that deliberately integrates the specialist vocational within liberal-humanistic base approach. These arguments were also strengthened by King, McKercher [31] in an attempt to balance the study program by providing a broadly grounded liberal education with the student's career desire. Thus, Morgan [32] proposed to rediscover these liberal humanistic values to be incorporated in the curriculum in order to produce a successful T\&H business' manager such as (1) qualities of self-awareness, (2) imagination, and (3) creativity. Likewise, Lewis [33] added the liberal aims including a holistic understanding of tourism that embracing both social science and business concerns to be reflected in the curriculum space.

At this point of view, among the plausible explanation of the arguments pertaining curriculum development, lead to the review of the division of T\&H curriculum development model approach with one portion concentrating its analysis from a broader social science assessment and the other half being dedicated to a business-oriented character. In practice, the T\&H curriculum model begin with an understanding of curriculum to function as a guideline of continuous logical process for teaching and learning activities toward the desired outcome. Indeed, it is to determine the desirable quality of education that affecting a graduate competence in creating fundamental role as a human being who are able to function socially and economically as well as maintain the well-being and effectiveness of higher education institution. 
Nevertheless, beyond the T\&H educational curriculum development approach and the content of the courses as a constant subject for debate lays a complex situation in concern of a recent condition prior taking curriculum development journey such as accounting a possibly T\&H curriculum challenge and gap.

\section{Method}

An explicit method to select, and critically appraise T\&H curriculum related publication that were included in the review was established. Bernard and Ryan [34] informed the systematic approaches for the relevant research, and to collect and analyse data from the studies. In practice, a Boolean logic search engine were utilized on Google scholar and collection in the university's library in order to provide the reviewed articles [35]. The EndNote X9 software tool were utilized to store and manage the result. At the first stages, altogether, the two search engines produced more than 60,000 published articles. The selection of full paper availability and smart group examination through EndNote X9 features activated the second stages. The third stages were done by reviewing on article's title, abstract, and keywords to determine whether the full-length research discussion was really related to the current research. Following to that, the stages yielded 44 papers of $\mathrm{T} \& \mathrm{H}$ curriculum development research data set that range from year 1982 thoroughgoing a recent one in 2017. Specifically, the final stages followed Braun and Clarke [36] six phases of thematic analysis in generating the four critical themes of the study and producing the report pertaining $\mathrm{T} \& \mathrm{H}$ curriculum challenges and gaps.

\section{T\&H Curriculum Challenges and Gaps}

Debate and argument have highlighted critical challenges facing the education regards fundamental changes in educational processes subject areas, and disciplines. The goal is to develop and support new ways of teaching and learning approaches, even pedagogies and practices, as well as the content knowledge for hospitality and tourism education through curriculum innovation and development [37-39].

The T\&H curriculum related studies for almost three decades support the preceding paragraph's argument as well as identify the challenges and gaps for the curriculum developer to have critical attention on such issues. Table 1 informs four themes of critical challenges and gaps regard curriculum developmental issues such as (1) the needs of information, communication and technology (ICT), (2) human resources concern - skill and knowledge gap and the attention to graduate's competency as well as career aspiration, (3) the responsiveness to industry-centered and expectation, and (4) the requirements for high-quality educational provision with effective teaching $\&$ learning practices to have significance research impact.

Table 1. The Challenges and Gaps of Tourism and Hospitality Curriculum

\begin{tabular}{cccc}
\hline Themes & Dimension & Authors & Year \\
\hline Information and communication technologies (ICT) needs & Challenges & {$[40]$} & 1986 \\
& {$[41]$} & 2014 \\
& {$[42]$} & 2014 \\
\hline
\end{tabular}




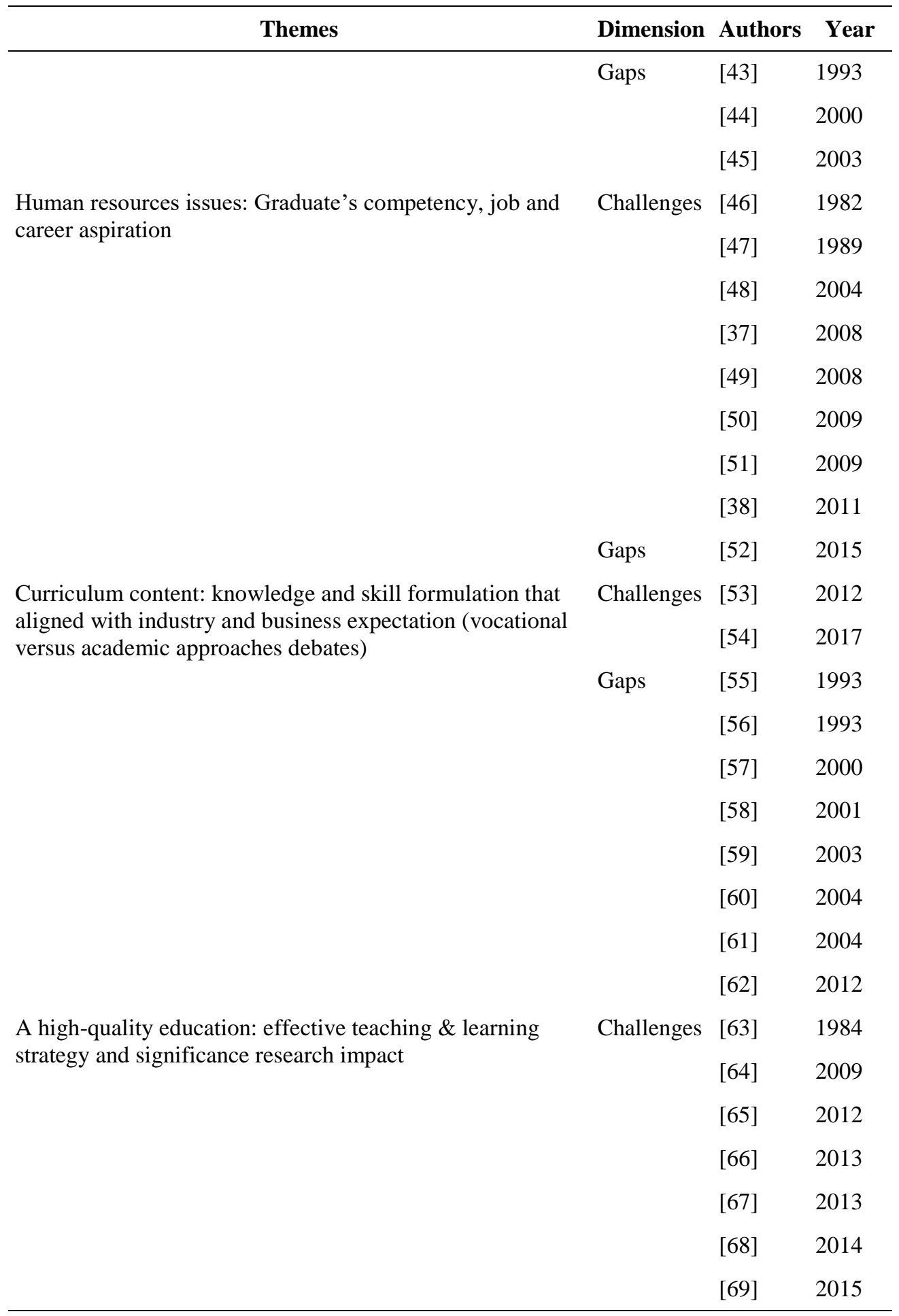




\begin{tabular}{|c|c|c|c|}
\hline Themes & Dimension & Authors & Year \\
\hline & Gaps & [70] & 1985 \\
\hline & & {$[71,72]$} & $\begin{array}{l}1990 / \\
1991\end{array}$ \\
\hline & & [73] & 1999 \\
\hline & & [74] & 2001 \\
\hline & & [75] & 2003 \\
\hline & & [48] & 2004 \\
\hline & & [76] & 2008 \\
\hline & & [51] & 2009 \\
\hline & & [77] & 2010 \\
\hline & & [78] & 2012 \\
\hline & & [79] & 2013 \\
\hline & & [80] & 2015 \\
\hline
\end{tabular}

Significantly, Marinakou and Giousmpasoglou [80] and Min, Swanger [81] highlighted the problems towards generic and soft skills key areas with industry professionals' expectation has caused the limited provision of $\mathrm{T} \& \mathrm{H}$ education, which is offered mainly at the vocational level such as human resource management, communication, people and relationships skills, customer service, and work ethics, particularly in Bahrain. In addition, Laws and Scott [68] highlighted the tourism's body of knowledge as a mosaic that challenges the theoretical core and disciplinary boundary.

Consequently, the development of T\&H curriculum has become more complex, regardless of the circumstances and approaches that curriculum developers need to take into account.

\section{Concluding Remark}

Important conclusions drawn from the preceding discussion about industrial growth force factors to educational curriculum pertaining development context convey educator's attention to the uncertainty of T\&H future curriculum. Besides, the all four themes curriculum challenges and gaps such as (1) the needs of information, communication and technology (ICT), (2) human resources concern - skill and knowledge gap and the attention to graduate's competency as well as career aspiration, (3) the responsiveness to industry-centred and expectation, and (4) the requirements for high-quality educational provision with effective teaching \& learning practices to have significance research impact. There is critical need to understand $\mathrm{T} \& \mathrm{H}$ as a discipline study at higher education level including an effective strategy of teaching and learning practices to function as the vehicle to equalize skill and knowledge to produce the desirable knowledgeable highly skill workforce. 
Theoretically, conceptually and empirically, an attempt to enhance student's learning to inform teaching and learning strategy at global higher educational level to adapt to rapidly changing demands of the current world - economically and socially, has brought the dialogues to constructivism point of view. The constructivist-thinking to curriculum development focus on teaching and learning activities in nurturing an effective learner approach as well as encourage a learner to be active and aware of social engagement pertaining learning interest. As such, Biggs [82] work in creating meaning of learning combined with instructional design theories has resulted 'constructive alignment' approach to guide teaching and learning strategic decision while at the same time align with the objective of learning outcomes to asses a learner performances. While, Kolb [83] 'experiential learning', Gardner [84], Gardner [85] 'multiple intelligences' and Myers, McCaulley [86] 'Myers-Briggs type indicator' (MBTI) focus on an experiment and strategy of learning preferences for both actors of teaching and learning activities in communicating and facilitating their own style through curriculum, particularly teachers and students. And, Lave and Wenger [87] 'legitimate peripheral participation (LPP)' of work-based and project-based learning offered comprehensive understanding of knowledge, skill, attitude, and action in the workplace through problem identification. Whereas, alternatively, Meyer and Land [88] 'threshold concept' idea provided a stimulation thinking to enhance a robust teaching and learning environment.

However, this is not to address as comparison study or even to contrast those various approaches. But, the way forward to have a comprehensive understanding in finding a boulevard to generate the complete learner through curriculum. The complete learner understood as $\mathrm{T} \& \mathrm{H}$ future educated workforce in references to all of that industrial phenomenon and closed the curriculum gaps as well as face the challenges.

In this sense, understanding the constructivist different theories, concept and model would be essential to initiate curriculum development journey towards meaning-outcomes curriculum model for learner's acquisitions on knowledge including skill to develop graduate's competitiveness within higher education institution.

Therefore, $\mathrm{T} \& \mathrm{H}$ educators or even managers in the industry obligate to generate breakthroughs. It is no longer appropriate to conduct the programs studies as business tools or produce job-ready graduate only. T\&H educators need to deliver a learner that is not only literate but a learner that possess a combination of knowledge, skills, and thinking to solve problems, to think creatively and to continue to learn in order to answer economic challenges, develop employment prospects and social responsibility. This is to understand since Kennedy, Chan [89] and Inui [26] argued that the aim of educational curriculum is to create the complete learner rather than merely concentrating upon what curriculum needs to offer - as it is not possible to incorporate all existing knowledge in one particular curriculum.

\section{References}

[1] 1. Gyr, U., The History of Tourism: Structures on the Path to Modernity. 2010.

[2] 2. Theobald, W.F.F., Global Tourism. 3 ed. 2012: Taylor \& Francis.

[3] 3. UNWTO International tourism to continue robust growth in 2013. 2013. Para 1.

[4] 4. UNWTO UNWTO Tourism Highlights: 2014 Edition. 2014.

[5] 5. UNWTO UNWTO Annual Report 2014. 2015.

[6] 6. UNWTO, Close to one billion international tourists in the first nine months of 2016, U.M.O.R.G. Sobrino, Editor. 2016.

[7] 7. UNWTO, UNWTO Annual Report 2016. 2017: Spain. 
[8] 8. Lugosi, P. and S. Jameson, Challenges in hospitality management education: Perspectives from the United Kingdom. Journal of Hospitality and Tourism Management, 2017. 31: p. 163-172.

[9] 9. Hsu, C.H., H. Xiao, and N. Chen, Hospitality and tourism education research from 2005 to 2014: "Is the past a prologue to the future?". International Journal of Contemporary Hospitality Management, 2017. 29(1): p. 141-160.

[10] 10. Dredge, D., D. Airey, and M. Gross, Creating the future, in The Routledge Handbook of Tourism and Hospitality Education, D. Dredge, D. Airey, and M. Gross, Editors. 2015, Routledge: Milton Park, Abingdon, Oxon.

[11] 11. Butler, R. and P. Jones, Conclusions - problems, challenges and solutions, in Tourism and Hospitality in the 21 st Century, A. Lockwood and S. Medlik, Editors. 2001, Elsevier. p. 300.

[12] 12. Airey, D., D. Dredge, and M. Gross, Tourism, hospitality and events education in an age of change, in The Routledge Handbook of Tourism and Hospitality Education, D. Dredge, D. Airey, and M. Gross, Editors. 2015, Routledge: Milton Park, Abingdon, Oxon.

[13] 13. Lockwood, A. and S. Medlik, Tourism and Hospitality in the 21st Century. 2001: Elsevier.

[14] 14. Affolter, D., The Tourism Market Place: New Challenges, in Tourism and Hospitality in the 21 st Century, A. Lockwood and S. Medlik, Editors. 2001, Elsevier. p. 240.

[15] 15. Muller, H., Tourism and Hospitality into 21st Century, in Tourism and Hospitality in the 21st Century, A. Lockwood and S. Medlik, Editors. 2001, Elsevier. p. 62.

[16] 16. Tribe, J., The Curriculum: a philosphic practice?, in The Routledge Handbook of Tourism and Hospitality Education, D. Dredge, D. Airey, and M. Gross, Editors. 2015, Routledge: Milton Park, Abingdon, Oxon.

[17] 17. Dredge, D., et al., The philosophic practitioner and the curriculum space, in The Routledge Handbook of Tourism and Hospitality Education, D. Dredge, D. Airey, and M. Gross, Editors. 2015, Routledge: Milton Park, Abingdon, Oxon.

[18] 18. Caton, K., On the practical value of a liberal education, in The Routledge Handbook of Tourism and Hospitality Education, D. Dredge, D. Airey, and M. Gross, Editors. 2015, Routledge: Milton Park, Abingdon, Oxon.

[19] 19. Thomas, R., Business elites, universities and knowledge transfer in tourism. Tourism Management, 2012. 33(3): p. 553-561.

[20] 20. Avornyo, R., BRIDGING THE GAP BETWEEN THE TOURISM INDUSTRY AND TERTIARY INSTITUTIONS OFFERING TOURISM IN GHANA: A CASE STUDY OF CAPE COAST. European Scientific Journal, 2014. 9(10).

[21] 21. Toohey, S., Designing Courses for Higher Education. 1999: ERIC.

[22] 22. Ackerman, D.B., Taproots for a New Century: Tapping the Best of Traditional and Progressive Education. Phi Delta Kappan, 2003. 84(5): p. 344-349.

[23] 23. Rogers, A. and P. Taylor, Participatory Curriculum Development in Agricultural Education. 1998(Rome: FAO).

[24] 24. Carl, A., Teacher Empowerment Through Curriculum Development: Theory Into Practice. 2009: Juta.

[25] 25. Lunenburg, F.C., Curriculum development: Deductive models. SCHOOLING, 2011. 2(1): p. 1 7.

[26] 26. Inui, Y., Rethinking Tourism Education: What Should Schools Teach? The Journal of Hospitality Leisure Sport and Tourism, 2006. 5(2): p. 25-35.

[27] 27. Tribe, J., Research paradigms and the tourism curriculum. Journal of Travel Research, 2001. 39(4): p. 442-448.

[28] 28. Tribe, J., The philosophic practitioner. Annals of tourism research, 2002. 29(2): p. 338-357.

[29] 29. Tribe, J., Balancing the vocational: The theory and practice of liberal education in tourism. Tourism and Hospitality Research, 2000. 2(1): p. 9-26.

[30] 30. Morrison, A. and G.B. O'Mahony, The liberation of hospitality management education. International Journal of Contemporary Hospitality Management, 2003. 15(1): p. 38-44.

[31] 31. King, B., B. McKercher, and R. Waryszak, A comparative study of hospitality and tourism graduates in Australia and Hong Kong. International Journal of Tourism Research, 2003. 5(6): p. 409-420. 
[32] 32. Morgan, M., From production line to drama school: higher education for the future of tourism. International Journal of Contemporary Hospitality Management, 2004. 16(2): p. 91-99.

[33] 33. Lewis, Rationalising a tourism curriculum for sustainable tourism development in small island states: A stakeholder perspective. Journal of Hospitality, Leisure, Sport and Tourism Education, 2005. 4(2): p. 4-15.

[34] 34. Bernard, H.R. and G.W. Ryan, Analyzing Qualitative Data: Systematic Approaches. 2010: SAGE Publications.

[35] 35. Hammer, P.L. and S. Rudeanu, Boolean methods in operations research and related areas. Vol. 7. 2012: Springer Science \& Business Media.

[36] 36. Braun, V. and V. Clarke, Using thematic analysis in psychology. Qualitative research in psychology, 2006. 3(2): p. 77-101.

[37] 37. Sheldon, P., et al., Tourism Education Futures, 2010-2030: Building the Capacity to Lead. Journal of Teaching in Travel \& Tourism, 2008. 7(3): p. 61-68.

[38] 38. Sheldon, P., D. Fesenmaier, and J. Tribe, The Tourism Education Futures Initiative (TEFI): Activating Change in Tourism Education. Journal of Teaching in Travel \& Tourism, 2011. 11(1): p. $2-23$.

[39] 39. Fidgeon, P.R., Tourism education and curriculum design: A time for consolidation and review? Tourism Management, 2010. 31(6): p. 699-723.

[40] 40. Var, T., et al., Tourism and computers: Quo vadis? Annals of Tourism Research, 1986. 13(1): p. 109-117.

[41] 41. Sigala, M. and E. Christou, Social computing in travel, tourism and hospitality. Computers in Human Behavior, 2014. 30: p. 771-772.

[42] 42. Ali, A., H.C. Murphy, and S. Nadkarni, Hospitality students' perceptions of digital tools for learning and sustainable development. Journal of Hospitality, Leisure, Sport \& Tourism Education, 2014. 15(0): p. 1-10.

[43] 43. Pavesic, D.V., Hospitality education 2005: Curricular and programmatic trends. Journal of Hospitality \& Tourism Research, 1993. 17(1): p. 285-294.

[44] 44. Sigala, M., et al., The diffusion and application of multimedia technologies in the tourism and hospitality industries. Information and Communication Technologies in Tourism 2000, ed. D.R. Fesenmaier, S. Klein, and D. Buhalis. 2000. 396-407.

[45] 45. Stamboulis, Y. and P. Skayannis, Innovation strategies and technology for experience-based tourism. Tourism management, 2003. 24(1): p. 35-43.

[46] 46. Waskey, F.H., Which way to professionalism?-some challenges for hospitality management. International Journal of Hospitality Management, 1982. 1(2): p. 120-122.

[47] 47. Sheldon, P., Professionalism in Tourism and Hospitality. Annals of Tourism Research, 1989. 16(4): p. 492-503.

[48] 48. Henry, B., et al., Future human resource challenges in the Caribbean hospitality industry. International Journal of Contemporary Hospitality Management, 2004. 16(7): p. 419-423.

[49] 49. Chen, B.T. and D. Gursoy, Preparing Students for Careers in the Leisure, Recreation, and Tourism Field. Journal of Teaching in Travel \& Tourism, 2008. 7(3): p. 21-41.

[50] 50. Chi, C.G. and D. Gursoy, How to help your graduates secure better jobs? An industry perspective. International Journal of Contemporary Hospitality Management, 2009. 21(3): p. 308322.

[51] 51. Lu, T. and H. Adler, Career Goals and Expectations of Hospitality and Tourism Students in China. Journal of Teaching in Travel \& Tourism, 2009. 9(1-2): p. 63-80.

[52] 52. Liu, H.H., Tourism Education: Using Curriculum Mapping to Shorten the Gap between Learning and Applying. Revista de Cercetare si Interventie Sociala,, 2015. 49: p. 127-138.

[53] 53. Gursoy, D., I. Rahman, and N. Swanger, Industry's Expectations from Hospitality Schools: What has changed? Journal of Hospitality \& Tourism Education, 2012. 24(4): p. 32-42.

[54] 54. Oktadiana, H. and K. Chon, Vocational Versus Academic Debate on Undergraduate Education in Hospitality and Tourism: The Case of Indonesia. Journal of Hospitality \& Tourism Education, 2017. 29(1): p. 13-24. 
[55] 55. Goodenough, R. and S. Page, Planning for tourism education and training in the 1990s: Bridging the gap between industry and education. Journal of Geography in Higher Education, 1993. 17(1): p. 57-72.

[56] 56. Lewis, R.C., Hospitality Management Education: Here Today, Gone Tomorrow? Journal of Hospitality \& Tourism Research, 1993. 17(1): p. 273-283.

[57] 57. Smith and C. Cooper, Competitive Approaches to Tourism and Hospitality Curriculum Design. Journal of Travel Research, 2000. 39(1): p. 90-95.

[58] 58. Milman, A., Hospitality and Tourism Curriculum Development. Journal of Teaching in Travel \& Tourism, 2001. 1(4): p. 65-76.

[59] 59. Tribe, J., Curriculum, Development and Conflict. Journal of Teaching in Travel \& Tourism, 2003. 3(1): p. 25-45.

[60] 60. Petrova, P. and P. Mason, The value of tourism degrees: a Luton-based case study. Education + Training, 2004. 46(3): p. 153-161.

[61] 61. Gursoy, D. and N. Swanger, An Industry-Driven Model of Hospitality Curriculum for Programs Housed in Accredited Colleges of Business. Journal of Hospitality \& Tourism Education, 2004. 16(4): p. 13-20.

[62] 62. Hidayat, N.K., The Emergence of Entrepreneur Competencies Toward Hospitality Management Education Transformation. Available at SSRN 2019667, 2012.

[63] 63. Pavesic, D.V., Educator - Industry Perceptions of Subject-Area Importance in Hospitality Programs. Journal of Hospitality \& Tourism Research, 1984. 9(1): p. 13-30.

[64] 64. Ayikoru, M., J. Tribe, and D. Airey, Reading Tourism Education: Neoliberalism Unveiled. Annals of Tourism Research, 2009. 36(2): p. 191-221.

[65] 65. Dredge, D., et al., The philosophic practitioner and the curriculum space. Annals of Tourism Research, 2012. 39(4): p. 2154-2176.

[66] 66. Wilson, E. and T. von der Heidt, Business as Usual? Barriers to Education for Sustainability in the Tourism Curriculum. Journal of Teaching in Travel \& Tourism, 2013. 13(2): p. 130-147.

[67] 67. Dredge, D., et al., Drivers of Change in Tourism, Hospitality, and Event Management Education: An Australian Perspective. Journal of Hospitality \& Tourism Education, 2013. 25(2): p. 89-102.

[68] 68. Laws, E. and N. Scott, Tourism research: building from other disciplines. Tourism Recreation Research, 2015. 40(1): p. 48-58.

[69] 69. Ayikoru, M., Neoliberalism and the new mangerialism in tourism and hospitality education, in The Routledge Handbook of Tourism and Hospitality Education, D. Dredge, D. Airey, and M. Gross, Editors. 2015, Routledge: Milton Park, Abingdon, Oxon. p. 118.

[70] 70. Waskey, F.H., Accreditation and Articulation: Are We Asking the Right Questions? Journal of Hospitality \& Tourism Research, 1985. 9(2): p. 65-71.

[71] 71. Collison, F. and P. Sheldon, An Empirical Study Of Employment Conditions For Tourism And Hospitality Faculty. Journal of Travel Research, 1991. 29(4): p. 40-46.

[72] 72. Sheldon, P. and F. Collison, Faculty Review Criteria in Tourism and Hospitality. Annals of Tourism Research, 1990. 17(4): p. 556-567.

[73] 73. Airey, D. and S. Johnson, The content of tourism degree courses in the UK. Tourism Management, 1999. 20(2): p. 229-235.

[74] 74. Ernawati, D., A Proposed Tourism Master's Degree Curriculum for Indonesia: The Experts' Views. Tourism Recreation Research, 2001. 26(3): p. 89-92.

[75] 75. Ernawati, D. and P. Pearce, Tourism courses at the higher education level in Indonesia: the perspectives of the stakeholders. Journal of teaching in travel \& tourism, 2003. 3(2): p. 1-18.

[76] 76. Barron, P., Education and talent management: implications for the hospitality industry. International Journal of Contemporary Hospitality Management, 2008. 20(7): p. 730-742.

[77] 77. Wang, J., H. Ayres, and J. Huyton, Is tourism education meeting the needs of the tourism industry? An Australian case study. Journal of Hospitality \& Tourism Education, 2010. 22(1): p. 814.

[78] 78. Penfold, P., L. Wei, and A. Ladkin, Developing Hospitality Education in China: A Case Study of Guilin Institute of Tourism. 2012. 8: p. 61-77. 
[79] 79. Hudson, S., Knowledge exchange: A destination perspective. Journal of Destination Marketing \& Management, 2013. 2(3): p. 129-131.

[80] 80. Marinakou, E. and C. Giousmpasoglou, Stakeholders' Views on the Development of a Higher Education Hospitality Program in Bahrain: Challenges and Opportunities. Journal of Hospitality \& Tourism Education, 2015. 27(2): p. 85-92.

[81] 81. Min, H., N. Swanger, and D. Gursoy, A Longitudinal Investigation of the Importance of Course Subjects in the Hospitality Curriculum: An Industry Perspective. Journal of Hospitality \& Tourism Education, 2016. 28(1): p. 10-20.

[82] 82. Biggs, J., Enhancing teaching through constructive alignment. Higher education, 1996. 32(3): p. 347-364.

[83] 83. Kolb, D.A., Experiental Learning. 1984, Englewood Cliff, NJ: Prentice Hall.

[84] 84. Gardner, H., Frames of mind: The theory of multiple intelligences. 2011: Basic books.

[85] 85. Gardner, H., Frames of Mind: The Theory of Multiple Intelligences. 1984, JSTOR.

[86] 86. Myers, I.B., et al., MBTI Handbook: A Guide to the development and use of the Myers-Briggs Type Indicator. 1998, washington: Consulting Psychologists Press.

[87] 87. Lave, J. and E. Wenger, Situated learning: Legitimate peripheral participation. 1991: Cambridge university press.

[88] 88. Meyer and Land, Threshold concept and troublesome knowledge: Linkages to Ways of Thinking and Practising within the Disciplines, E.T.-L.E.i.U.C. Project, Editor. 2003, School of Education, University of Edinburgh.

[89] 89. Kennedy, K.J., J.K.s. Chan, and P.K. Fok, Holding policy-makers to account: exploring 'soft' and 'hard' policy and the implications for curriculum reform. London Review of Education, 2011. 9(1): p. 41-54. 